\title{
Recent Doctoral Dissertations About The Bahamas and by The College of The Bahamas Faculty
}

\author{
Berthamae L. Walker ${ }^{1}$
}

\section{NOTES}

There has been a surprising amount of research conducted in The Bahamas, about The Bahamas and by Bahamians. Thanks to the many databases now freely available on the Internet, much of this research can now be easily located. For example, a search of the WorldCat database (http://www.worldcat.org) using the keywords "Bahamas OR Bahamian" and filtering the results to "thesis/dissertation” produces a result of over 700 titles - the majority of which are theses at the doctoral and master's levels.

Breaking down the results by year published produces some interesting figures. The first dissertation about the Bahama Islands was written in 1905 . Throughout the first half of the $20^{\text {th }}$ century approximately 50 more studies were conducted at both master's and doctoral levels. Then in the mid1970s there was an "explosion" of research about the Bahamas which seems to have continued unabated. Dissertations and theses written at all academic levels have numbered over 20 annually since then.

An analysis of the Bahamian-content theses by subject area or discipline is also quite revealing. The top three subject areas are Education, Geology/Earth Science and Biological Sciences followed by History, Economics and Business. One caveat about this "data": only theses and dissertations that have been catalogued by participating university libraries and reported to the WorldCat database have been counted. As well, Bahamians writing dissertations on "non-Bahamian" topics, such as a dissertation in physics or chemistry, would not be included. However, the trends in the topics of research and scholarship about the Bahamas clearly reflect the priorities of a young country as well as the accessibility of its abundant natural resources for research.

Previous volumes of The College of The Bahamas Research Journal listed recent doctoral dissertations written by faculty of the College. The tradition continues but with a slight enhancement: the list now includes all doctoral dissertations written since 2002 that have been reported in the WorldCat database. In addition, dissertations written by current College faculty that had not been listed in earlier volumes of the journal have been included - they have been highlighted. Some of the dissertations on the listing are available in the College libraries. Please check the Library’s online catalogue on http://cobweb.info.bs.

Any errors or omissions will be corrected in the next volume!

\footnotetext{
${ }^{1}$ Berthamae L. Walker, Deputy Director, Libraries and Instructional Media Services, The College of The Bahamas, P.O. Box N-4912, Nassau, Bahamas.

Acknowledgements: Thanks to Jeannie Gibson, Planning Department, Office of The President and to Clarice Forbes, Hilda Bowen Library, Libraries and Instructional Media Services, for their assistance.

E-mail: bwalker@cob.edu.bs

How to cite this article in APA (7th ed.) style: Walker, B. L. (2008). Recent doctoral dissertations about The Bahamas and by The College of The Bahamas faculty. The College of The Bahamas Research Journal, 14, 51-54. https://doi.org/10.15362/ijbs.v14i0.103
} 


\section{8}

Green, M. L. (2008). Assessment of genetic population structure, promiscuity, and paternity in free-ranging Atlantic spotted dolphins, Stenella frontalis, in the Bahamas. Thesis (Ph.D.)—Florida Atlantic University, 2008.

Higgs, D. M. (2008). Behind the smile negotiating and transforming the tourism-imposed identity of Bahamian women. Thesis (Ph.D.)—Bowling Green State University, 2008. http://rave.ohiolink.edu/etdc/view?acc\%5Fnum=bgsu1207582369.

Stallings, C. D. (2008). Indirect effects of fishing on predators and their prey. Thesis (Ph.D.)—Oregon State University, 2008.

Villiger, E. J. (2008). Radar and multispectral image fusion options for improved land cover classification. Thesis (Ph.D.)—George Mason University, 2008. http://hdl.handle.net/1920/3085. (Research conducted on Andros--Ed.)

\section{7}

Francis, T. P. (2007). Identity politics: Postcolonial theory and writing program instruction. Thesis (Ph.D.) University of South Florida, 2007. http://purl.fcla.edu/usf/dc/et/SFE0002159.

$\mathrm{Hu}, \mathrm{X}$. (2007). Seagrass-mediated carbonate dissolution and early diagenesis in Bahamas Bank sediments. Thesis (Ph.D.)—Old Dominion University, 2007.

Reeder, S. L. (2007). Comparative morphology and dynamics of Holocene carbonate systems, northwestern Abaco Islands, Bahamas. Thesis (Ph.D.)—University of Miami, 2007.

Semon, K. L. (2007). Life history strategies and population dynamics of stony corals (Cnidaria: Scleractinia) in marginal habitats of the Bahama Banks: Implications for long-term survival and persistence of coral communities. Thesis (Ph.D.)-University of Miami, 2007.

Ward, S. (2007). Perceptions of public school teachers regarding the effectiveness of the Career Path System evaluation instrument in the Bahamas. Thesis (Ph.D.)—Andrews University, School of Education, 2007.

Wormald, C. L. (2007). Effects of density and habitat structure on growth and survival of harvested coral reef fishes. Thesis (Ph.D.) - University of Rhode Island, 2007. http://0digitalcommons.uri.edu.helin.uri.edu/dissertations/AAI3277014.

\section{6}

Higgs, J. M. (2006). Colonial education, African amnesia: Diasporic African historical amnesia in Fox Hill, Bahamas. Thesis (Ed.D.) — University of St. Thomas (Saint Paul, Minn.), 2006.

Stewart, K. L. (2006). Human-dolphin encounter spaces a qualitative investigation of the geographies and ethics of swim-with-the-dolphins programs. Thesis (Ph.D.)—Florida State University, 2006.

Voss, J. D. (2006). Coral disease dynamics and environmental drivers in the northern Florida Keys and Lee Stocking Island, Bahamas. Thesis (Ph.D.)—Florida International University, 2006. 


\section{5}

Came, R. E. (2005). Abrupt climate change in the Atlantic Ocean during the last 20,000 years: Insights from multielement analysis of benthic and planktic foraminifera and coupled OA-GCM. Thesis (Ph.D.) - Joint Program in Oceanography/Applied Ocean Science and Engineering (Massachusetts Institute of Technology, Dept. of Earth, Atmospheric, and Planetary Sciences; and the Woods Hole Oceanographic Institution), 2005.

Knapp, C. R. (2005). Ecology and conservation of the andros iguana (Cyclura cychlura cychlura). Thesis (Ph.D.) - University of Florida, 2006. http://purl.fcla.edu/fcla/etd/UFE0013053.

Lund, D. C. (2006). Gulf stream temperature, salinity and transport during the last millennium. Thesis (Ph.D.)Joint Program in Oceanography (Massachusetts Institute of Technology, Dept. of Earth, Atmospheric, and Planetary Sciences; and the Woods Hole Oceanographic Institution), 2006.

Nero, V. L. (2005). Abiotic and biotic influences on the composition of nearshore marine communities of the Bahamas. Thesis (Ph.D.) —University of Miami, 2005.

Thornhill, D. J. (2005). Establishment and maintenance of cnidarian-dinoflagellate symbioses. Thesis (Ph.D.)University of Georgia, 2005.

Toppin, V. (2005). The role of the histaminergic system in the regulation of respiration. Thesis (Ph.D.) - Howard University, 2005.

Walker, B. L. (2005). An investigation of the feasibility of using web-centric methods versus traditional face-to-face menthods in delivering a course in bibliographic instruction. Thesis (Ph.D.) -Nova Southeastern University, 2005.

\section{4}

Anderson, N. J. (2004). Comparing alternative landscapes power negotiations in enslaved communities in Louisiana and the Bahamas: An archaeological and historical perspective. Thesis (Ph.D.)—University of Texas at Austin, 2004. http://www.lib.utexas.edu/etd/d/2004/andersonn64577/andersonn64577.pdf\#page=3

Bodo Slotta, T. A. (2004). Phylogenetics of the Malacothamnus alliance (Malvaceae) assessing the role of hybridization and molecular and morphological variation in species delineation. Thesis (Ph.D.)-Virginia Polytechnic Institute and State University, 2004. http://scholar.lib.vt.edu/theses/available/etd-07052004222328/

Dowgiallo, M. J. (2004). Patterns in diversity and distribution of benthic molluscs along a depth gradient in the Bahamas. Thesis (Ph.D.)—University of Maryland, College Park, 2004. http://hdl.handle.net/1903/2005.

Overholtzer-McLeod, K. L. (2004). Population dynamics of coral-reef fishes: Spatial variation in emigration, mortality, and predation. Thesis (Ph.D.) — Oregon State University, 2004.

Rolle, C. R. (2004). Religiosity, school satisfaction, and the decision to teach in Christian schools: A study evidence from American and Bahamain high schools. Thesis (Ed. D.) —La Sierra University, 2004.

Romer, V. A. (2004). Attitudes of junior high teachers towards teaching students with learning disabilities in inclusive classes in public schools in New Providence, Bahamas. Thesis (Ph.D.)—Andrews University, School of Education, 2004

Warrior, H. V. (2004). Parameterization of the light models in various general ocean circulation models for shallow waters. Thesis (Ph.D.) - University of South Florida, 2004. http://purl.fcla.edu/fcla/etd/SFE0000394 


\section{3}

Curry, Z. A. (2003). Distance education, training and telehealth: New concepts in the health care system of The Commonwealth of The Bahamas. Social Action Project (Ph.D.) - Union Institute \& University, Cincinnati, 2003.

Gutierrez-Rodriguez, C. (2003). Reproductive biology of the Caribbean gorgonian Pseudopterogorgia elisabethae and its effects on genetic variation. Thesis (Ph.D.) - University of New York at Buffalo, 2003.

Katsivela, M.-E. (2003). Multimodal carrier liability in the U.S. and Canada towards uniformity of applicable rules? These (LL.D.)—Université de Montréal, 2003.

Moran, K. L. (2003). Simulated green turtle grazing: effects on structure and productivity in seagrass (Thalassia testudinum) beds in the central Bahamas. Thesis (Ph.D.) —University of Florida, 2003.

Neely-Smith, S. L. (2003). The influence of self-esteem and self-silencing on self-efficacy for negotiating safer sex behaviors in urban Bahamian women. Thesis (Ph.D.) -Barry University, 2003.

Newman, S. P. (2003). Spatial and temporal variation in diet and prey preference of nursery-bound juvenile lemon sharks (Negaprion brevirostris) at Bimini, Bahamas. Thesis (Ph.D.)—University of Plymouth, 2003.

Storr, V. H. (2003). Enterprising slaves and master pirates: Understanding economic life in the Bahamas. Thesis (Ph.D.) - George Mason University, 2003.

Stuart, Y. (2003). The road from monopoly to duopoly: Broadcasting in the Bahamas, 1930-2000. Thesis (Ph.D.) University of Alabama, 2003.

Waldron, L. (2003). Isabel Allende: Literary inheritance and the establishment of a new dimension in Chilean female fiction. Thesis (Ph.D.) - University of the West Indies, St. Augustine, Trinidad and Tobago, 2003.

Ward, A.E. (2003). Equity in the provision and use of health care services in the Bahamas. Thesis (Ph.D.) University of Birmingham, 2003.

\section{2}

Almany, G. R. (2002). Role of priority effects and habitat complexity in coral-reef fish communities. Thesis (Ph.D.) - Oregon State University, 2002.

Gardner, D. O. N. (2002). The universal potential energy curve: A valence state approach. Thesis (Ph.D.) University of the West Indies, Mona, Jamaica, 2002.

Hackert, S. (2002). "I did done gone”: Typological, sociolinguistic, and discourse pragmatic perspectives on past temporal reference in urban Bahamian Creole English. Thesis (Ph.D.)—Ruprecht-Karls-University, Heidelberg, Germany, 2002

Kraut, A. C. (2002). Re-framing the vernacular: The dance praxis of Zora Neale Hurston. Thesis (Ph.D.)Northwestern University, 2002.

Robinson, L. F. (2002). Pleistocene climate chronology and ocean circulation in the Bahamas using U-series nuclides. Thesis (D. Phil.) —University of Oxford, 2002.

Shell-Weiss, M. R. (2002). "They all came from someplace else": Miami, Florida's immigrant communities, 18961970. Thesis (Ph.D.)—Michigan State University, 2002.

Thompson, K. A. (2002). The tropicalization of the Anglophone Caribbean: The picturesque and the aesthetics and politics of space in Jamaica and the Bahamas. Thesis (Ph.D.)—Emory University, 2002. 